\title{
Sintering effects on chemical and physical properties of bioactive ceramics
}

\author{
Lukasz WITEK ${ }^{a, b,}{ }^{*}$, James SMAY ${ }^{a}$, Nelson R. F. A. SILVA ${ }^{c}$, \\ Teja GUDA ${ }^{d}$, Joo L. ONG ${ }^{d}$, Paulo G. COELHO ${ }^{b, e}$

\begin{abstract}
${ }^{a}$ School of Chemical Engineering, Oklahoma State University, 423 Engineering North, Stillwater, OK, USA
${ }^{b}$ Department of Biomaterials and Biomimetics, New York University, 345 East 24th Street, 804S New York, NY, USA

${ }^{c}$ Department of Operative Dentistry, Universidade Federal de Minas Gerais, Pampulha, Belo Horizonte, MG, Brazil

${ }^{d}$ Department of Biomedical Engineering, University of Texas San Antonio, One UTSA Circle, San Antonio, TX, USA

${ }^{e}$ Department of Periodontology and Implant Dentistry, College of Dentistry, New York University, 345 East 24th Street, New York, NY, USA
\end{abstract}

Received: March 01, 2013; Revised: May 16, 2013; Accepted: June 13, 2013

(CThe Author(s) 2013. This article is published with open access at Springerlink.com

\begin{abstract}
The objective of this study was to characterize the chemical and physical properties of bioactive ceramics prepared from an aqueous paste containing hydroxyapatite (HA) and beta tri-calcium phosphate $(\beta-\mathrm{TCP})$. Prior to formulating the paste, HA and $\beta$-TCP were calcined at $800{ }^{\circ} \mathrm{C}$ and $975{ }^{\circ} \mathrm{C}(11 \mathrm{~h})$, milled, and blended into $15 \% / 85 \% \mathrm{HA} / \beta$-TCP volume-mixed paste. Fabricated cylindrical rods were subsequently sintered to $900{ }^{\circ} \mathrm{C}, 1100{ }^{\circ} \mathrm{C}$ or $1250{ }^{\circ} \mathrm{C}$. The sintered specimens were characterized by helium pycnometry, X-ray diffraction (XRD), Fourier transform-infrared (FT-IR), and inductively coupled plasma (ICP) spectroscopy for evaluation of porosity, crystalline phase, functional-groups, and $\mathrm{Ca}: \mathrm{P}$ ratio, respectively. Mechanical properties were assessed via 3-point bending and diametral compression. Qualitative microstructural evaluation using scanning electron microscopy (SEM) showed larger pores and a broader pore size distribution (PSD) for materials sintered at $900{ }^{\circ} \mathrm{C}$ and $1100{ }^{\circ} \mathrm{C}$, whereas the $1250{ }^{\circ} \mathrm{C}$ samples showed more uniform PSD. Porosity quantification showed significantly higher porosity for materials sintered to $900{ }^{\circ} \mathrm{C}$ and $1250{ }^{\circ} \mathrm{C}(p<0.05)$. XRD indicated substantial deviations from the $15 \% / 85 \% \mathrm{HA} / \beta$-TCP formulation following sintering where lower amounts of HA were observed when sintering temperature was increased. Mechanical testing demonstrated significant differences between calcination temperatures and different sintering regimes $(p<0.05)$. Variation in chemical composition and mechanical properties of bioactive ceramics were direct consequences of calcination and sintering.
\end{abstract}

Keywords: bone graft material; chemical/physical characterization; sintering; bi-phasic calcium phosphate (BCP)

\section{Introduction}

Bioceramics, such as hydroxyapatite (HA) and beta

* Corresponding author.

E-mail: lukasz.witek@okstate.edu tri-calcium phosphate $(\beta-\mathrm{TCP})$, possess two of the ideal characteristics for grafting procedures: osteoconduction and osseointegration [1]. Pure HA has great osteoconductive properties, ability to support the growth of bone over the implant surface, and chemical composition comparable to the inorganic component of bone [2]. HA has a high initial compressive strength, 
but low dissolution kinetics in vivo [3]. Additionally, its slow resorption rates prompted development of more soluble $\beta$-TCP ceramics [4]. While it has been shown that $\beta$-TCP goes through resorption over a $6-18$ month period, it is arguable that it may be too rapid $[3,4]$. Mixtures of HA and $\beta$-TCP ceramic powders have been used to achieve an intermediate solubility and better control of degradation/dissolution rate $[5,6]$.

This study addresses two specific questions with respect to the materials used in grafting processes for boney defects. First is the question of chemistry of the aqueous paste after all processing steps are completed. Is the composition of the ceramic the same as that used to initially formulate the feedstock? More specifically, is there any alteration in the ratio of HA and $\beta$-TCP in mixed ceramic scaffolds? The feedstock material is formulated by mechanical mixing of one or two commercially available ceramic powders. The powders are typically pre-processed by calcining at a lower temperature (c.a., $\quad 800-1000{ }^{\circ} \mathrm{C}$ ) followed by subsequent milling to refine particle size and shape. Then, after fabricating the feedstock and printing, the green ceramic body is subjected to sintering at higher temperatures in a furnace (c.a., $900-1250{ }^{\circ} \mathrm{C}$ ) for $4 \mathrm{~h}$.

The second question is addressed: how does processing affect the overall mechanical properties of the resultant ceramic material? The most obvious variables for strength of ceramics are the grain size and flaw (pore) population. Since microporosity, which can be achieved through incomplete sintering, within rods is desirable to a certain extent from a biological function standpoint, what is the overall effect on strength?

While the macroscopic arrangement of lattice-based bioactive ceramic scaffolds (LBBCS) is well controlled through respective fabrication technology and its associated sintering shrinkage $[4,7]$, its chemistry and internal material properties can be significantly altered depending on its composition and subsequent processing steps. For instance, sintering temperature range of $\beta$-TCP must be between $1100{ }^{\circ} \mathrm{C}$ and $1250{ }^{\circ} \mathrm{C}$, as higher temperatures will lead to its transformation to $\alpha$-TCP [8]. Sintering temperatures will also affect microporosity, specific surface area, density and porosity, thereby affecting the scaffold's dissolution properties over time in vivo. Additionally, if high temperatures are utilized, increases in density, grain size, compressive, flexural and torsional strength may be achieved [6]. From a fracture toughness standpoint, increased levels may be achieved at sintering temperatures between $1100{ }^{\circ} \mathrm{C}$ and $1150{ }^{\circ} \mathrm{C}$ while decreased levels have been observed at sintering temperatures higher than $1250{ }^{\circ} \mathrm{C}$ [6].

Previous observations and studies regarding bi-phasic calcium phosphate (BCP), which have not concentrated on correlating chemical properties with mechanical properties, have shown that strength among other properties has varied with sintering temperatures $[9,10]$. Thus, further physicochemical characterization of LBBCS is desirable and will allow further development of such systems for varied clinical applications.

\section{Materials and methods}

\subsection{Ink preparation}

The feedstock, a colloidal gel, which is referred to, as "ink", was fabricated into cylindrical rods. This colloidal gel was fabricated through a series of powder processing steps beginning with calcining, attrition milling and drying of the individual base materials. HA (Product 10185602, Lot 43640, Honeywell, Germany) was calcined at $800{ }^{\circ} \mathrm{C}$ or $975{ }^{\circ} \mathrm{C}$ for $11 \mathrm{~h}$ followed by cooling and milling in distilled water for approximately $30 \mathrm{~min}$ using an attrition mill (01-Lab Attritor, Union Process, Akron, OH, USA) with a charge of $3 \mathrm{~mm}$ diameter zirconia milling media and a mill speed of approximately $120 \mathrm{rpm}$. The same processing method was used for $\beta$-TCP (Product 21218, Lot 1305078, Sigma-Aldrich, Germany) [11]. After milling, the slurry was separated from the milling media and dried in a low-temperature oven $\left(\sim 37^{\circ} \mathrm{C}\right)$ to yield a dry ceramic powder. The commercially available particle characteristics are unsuitable for ink formulation due to presence of nanoporosity in the particles and a non-equiaxial particle shape. Therefore, it requires calcining and milling processes to remove these limitations and yield a powder suitable for further processing.

After calcining, milling and drying, the colloidal gel was formulated by precise addition of components in a specific order. To produce a $45 \mathrm{ml}$ batch of the colloidal gel, first, $\sim 20 \mathrm{~g}$ of $5 \mathrm{~mm}$ diameter round zirconia milling media, a pre-calculated amount of distilled water $\left(\mathrm{DI}-\mathrm{H}_{2} \mathrm{O}\right)$, and $1.4 \mathrm{~g}$ of dispersant molecule (Darvan ${ }^{\circledR} 821$ A, R.T. Vanderbilt Company, Inc., Norwalk, CT, USA) followed by appropriately 
calculated amounts of HA and $\beta$-TCP ceramic powders were added to a $250 \mathrm{ml}$ mixing cup (Thinky Inc., Japan). The mixing cup was placed in a non-contact planetary mixer (model AR-250, Thinky Inc., Tokyo, Japan) for $3 \mathrm{~min}$ at $2000 \mathrm{rpm}$. The cup was then placed in a water bath for $\sim 5 \mathrm{~min}$ to cool. Next, an aliquot of hydroxypropyl methylcellulose (Methocel F4M, Dow Chemical Company, Midland, MI, USA) stock solution (5\% by weight in water) was added at $7 \mathrm{mg} / \mathrm{ml}$ of ceramic and the suspension was again mixed for an additional $2 \mathrm{~min}$ at $2000 \mathrm{rpm}$. The final step was the addition of poly(ethlyenimine) (PEI) (molecular weight $=50-100 \mathrm{kDa}$, ICN Biomedical, Aurora, OH, USA) as a $10 \%$ aqueous stock solution. Initially, $1 \mathrm{ml}$ of PEI solution was added and mixed for $30 \mathrm{~s}$, then PEI solution was added drop-wise followed by mixing until reaching the desired consistency, which when a spatula dragged through the paste leaving a well-defined trench. These characteristics were well described by Smay et al. in previous publications [12].

\section{2 Methods}

\section{2. 1 Sample fabrication}

Rods of two different HA/ $\beta$-TCP ratios (volume fraction) were fabricated for evaluating the chemical and physical properties before and after the sintering process. The first sets of samples were compromised of $15 \% / 85 \% \mathrm{HA} / \beta$-TCP colloidal gel. A subsequent set of $100 \%$ HA rods were used as a control. The previously fabricated colloidal gel was loaded into $1 \mathrm{ml}$ Leur Lock syringes (BD, Franklin Lakes, NJ, USA) and left open to atmosphere at the Leur Lock end to allow drying of the charge. A total of 220 syringes were filled in this manner and allowed to dry for $\sim 48 \mathrm{~h}$ in an oven set to $\sim 75{ }^{\circ} \mathrm{C}$. After drying, the green state ceramic rod was removed by applying air pressure to the Leur Lock end of the syringe. Only rods of high quality (i.e., no cracks or other visible flaws) were retained for further characterization. The rods were sectioned using a diamond saw (Hi-Tech Diamond, Moorpark, CA, USA) to the dimensions: $18 \mathrm{~mm}$ in length and $4.1 \mathrm{~mm}$ in diameter (Fig. 1).

\section{2. 2 Chemical characterization}

After preparation of the green state rods and separation into three groups based on sintering temperature, they were placed into a high temperature furnace Thermolyne 46100 (Branstead, Dubuque, IA, USA). The samples were subjected to three different firing protocols with maximum sintering temperatures of

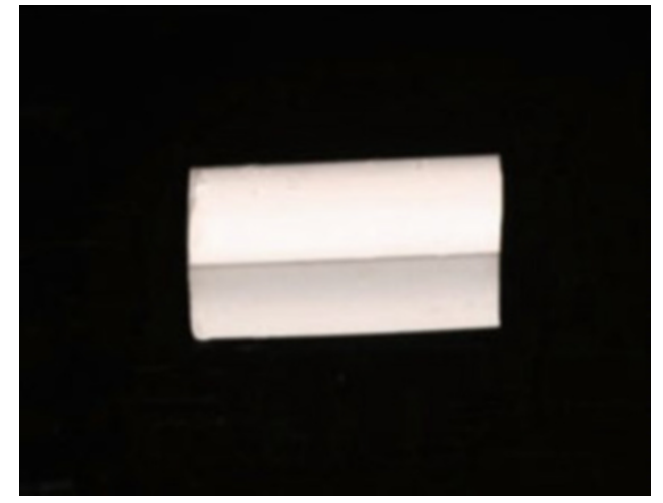

Fig. 1 Digital image of rod used for 3-point bending and diametral compression testing.

\section{$900{ }^{\circ} \mathrm{C}, 1100{ }^{\circ} \mathrm{C}$ and $1250{ }^{\circ} \mathrm{C}$ for $4 \mathrm{~h}$.}

Following the sintering process, porosity of the ceramic samples was characterized using helium pycnometry (Accupyc 1340, Norcross, GA, USA) to measure the true solid volume of the samples $\left(V_{\text {solid }}\right)$ by averaging across 10 independent measures per specimen ( $n=10$ /group). The length and diameter of each sample were determined by averaging three independent measurements to calculate the volume of the bounding cylinder ( $\left.V_{\text {cylinder }}\right)$. This allowed computation of porosity as the void volume fraction was [13]

$$
\text { Void volume fraction }=1-\left(V_{\text {solid }} / V_{\text {cylinder }}\right)
$$

To determine the crystalline phases present, $\mathrm{X}$-ray powder diffraction (XRD) spectra (Philips X'Pert X-ray diffractometer, Westborough, MA, USA) were used following the sintering protocols. Three different spectra for each calcination and sintering temperature (including green state) were obtained ( $n=3 /$ group). The diffractometer, using a curved crystal monochromator, was operated at $45 \mathrm{~mA}$ and $45 \mathrm{kV}$, and scanned in the $2 \theta$ range of $20^{\circ}-40^{\circ}$ with a step size of $0.02^{\circ}$ at $3 \mathrm{~s}$ per step [14].

In correlation with XRD, a Rietveld refinement analysis was performed. The data was collected from Philips X'Pert X-ray diffractometer, which subsequently exported data to " $x y$ " format. This raw data was then input into Material Analysis Using Diffraction (MAUD) (University of Trento, Trento, Italy) software for quantitative analysis. Rietveld analysis utilized the samples from previous XRD spectra (i.e., peaks, heights, widths and positions). A least square fit approach was utilized to measure scans until replicating a theoretical scan based on the structure in Inorganic Crystal Structure Data Base 
(ICSD) $[15,16]$. The background, cell parameters, preferred orientation, peak asymmetry, atomic positions, site occupancy factors and global vibrational parameters were refined. The calculated and observed patterns were plotted by least squares method until a minimum was reached. Five iterations were utilized and the integrated intensities and the peak heights were related to a scale factor. The fraction of each phase was determined by

$$
W_{i}=\frac{S_{i}(Z M V)_{i}}{\sum\left[S_{j}\left(Z M V_{j}\right)\right]}
$$

where $W_{i}$ is the weight fraction of the phase; $S$ is the scale factor; $Z$ is the number of formulas per unit cell; $M$ is the mass of the formula unit; $V$ is the unit cell volume; and $i$ and $j$ are the phase under analysis and all phases in the system, respectively [17].

Additionally, calcium (Ca) and phosphrous (P) concentrations were determined using inductive calcium plasma (ICP) spectroscopy (Thermo Jarell Ash, Trace Advantage, Franklin, MA, USA). For this purpose, $10 \mathrm{mg}$ of powder $(15 \% / 85 \% \mathrm{HA} / \beta$-TCP green state and 3 experimental groups: sintered to final temperatures of $900{ }^{\circ} \mathrm{C}, 1100{ }^{\circ} \mathrm{C}$ and $1250{ }^{\circ} \mathrm{C}$ ) was dissolved in $35 \% \mathrm{HCl}$ solution and mixed $100 \mathrm{ml}$ of double distilled water in a volumetric flask. Suitable standard solutions for $\mathrm{Ca}(0,20$ and $40 \mathrm{ppm})$ and $\mathrm{P}(0$, 10 and $40 \mathrm{ppm}$ ) were prepared from $100 \mathrm{ppm}$ standard solutions of the respective elements (Fisher Scientific, Pittsburgh, PA, USA). Each specimen in solution and standard solutions were pumped through argon plasma, which was excited by a $2 \mathrm{~kW}, 27.12 \mathrm{MHz}$ radio frequency generator [14].

\section{2. 3 Mechanical testing}

The flexural stress of all groups was determined via 3-point bending test using a universal testing machine (Instron Series 5560, Norwood, MA, USA) ( $n=12$ /group) equipped with a $1 \mathrm{kN}$ load cell and the extension rate of $1 \mathrm{~mm} / \mathrm{min}$, set to load to failure [14]. The flexural stress $(\sigma)$ for cylindrical rods was calculated from

$$
\sigma=\frac{8 P L_{0}}{\pi D^{3}}
$$

where $P$ is the compressive load; $D$ is the specimen diameter; and $L_{0}$ is the span of lower supports $(10 \mathrm{~mm})$.

While the tensile stress was measured using diametral compression testing method ( $n=12$ /group) on a universal testing machine (Instron Series 5560, Norwood, MA, USA) equipped with a $1 \mathrm{kN}$ load cell and the compression rate of $1 \mathrm{~mm} / \mathrm{min}$, the rods were sectioned using a diamond saw (Hi-Tech Diamond, Moorpark, CA, USA) to a length of twice the dimension of the diameter $(\sim 8.2 \mathrm{~mm})$. Tensile stress was calculated utilizing the formula

$$
\sigma=\frac{2 P}{\pi D l}
$$

where $P$ is the compressive load; $D$ is the specimen diameter; and $l$ is the specimen length [18].

\section{3 Statistical analysis}

For statistical evaluation, analysis of variance (ANOVA) at a 95\% confidence interval by using Statgraphics Plus 4.0 (Warrenton, VA, USA) was utilized considering calcination temperature and sintering temperatures as independent variables. Shrinkage, porosity, flexural strength, tensile strength, crystalline phase content and $\mathrm{Ca}: \mathrm{P}$ ratio were considered as dependent variables. Multiple comparisons between groups were performed by Tukey's post-hoc test.

\section{Discussions/conclusions}

Being that a wide range of physical and chemical properties can be achieved with this particular bioactive ceramic by modifying specific parameters, such as the HA/ $\beta$-TCP ratio, calcining and/or sintering temperature [3], these materials have been used to fabricate preformed implants and have shown considerably greater mechanical strength in comparison to other bioceramics used for similar bone grafting purposes [3]. The present study aimed to physically and chemically characterize bioactive ceramic rods prepared as $15 \% / 85 \%$ HA/ $\beta-\mathrm{TCP}$, calcined at two calcination temperatures $\left(800{ }^{\circ} \mathrm{C}\right.$ and $975{ }^{\circ} \mathrm{C}$ ), and subjected to three different sintering regimens: $900{ }^{\circ} \mathrm{C}, 1100{ }^{\circ} \mathrm{C}$ and $1250{ }^{\circ} \mathrm{C}$.

The advantage of this material, which is fabricated to an aqueous paste, allows for fabrication of scaffolds utilizing solid free form (SFF) also known as robocasting. This technique allows for the production of variety of complex structures utilizing $\mathrm{CAD} / \mathrm{CAM}$ software in addition to utilizing computed tomography scans exported to a specific file type which can in turn be fabricated to a specific defect, capable of reproducing the same structure consistently [19].

$\mathrm{XRD}$ of the as-received materials prior to 
calcination primarily showed HA and $\beta$-TCP crystalline phases for the individual HA and $\beta$-TCP powders. However, phase quantification through Rietveld refinement showed trivial fractions of $\beta$-TCP, calcium pyrophosphate $\left(\mathrm{Ca}_{2} \mathrm{P}_{2} \mathrm{O}_{7}\right)$, and calcium oxide $(\mathrm{CaO})$ for the $\mathrm{HA}$ as-received material, and minor fractions of $\mathrm{HA}, \mathrm{Ca}_{2} \mathrm{P}_{2} \mathrm{O}_{7}$ and $\mathrm{CaO}$ for the $\beta$-TCP starting material. Given that the aqueous pastes were fabricated without considering the presence of minor quantities of other calcium phosphate based phases, the intended composition of the $15 \% / 85 \% \mathrm{HA} / \beta$-TCP was slightly shifted from what was originally intended.

The XRD data from $15 \% / 85 \%$ HA/ $\beta$-TCP materials from both calcination groups (Figs. 2 and 3 ) at the different stages including green state, sintered to $900{ }^{\circ} \mathrm{C}, 1100{ }^{\circ} \mathrm{C}$ and $1250{ }^{\circ} \mathrm{C}$, were subjected to

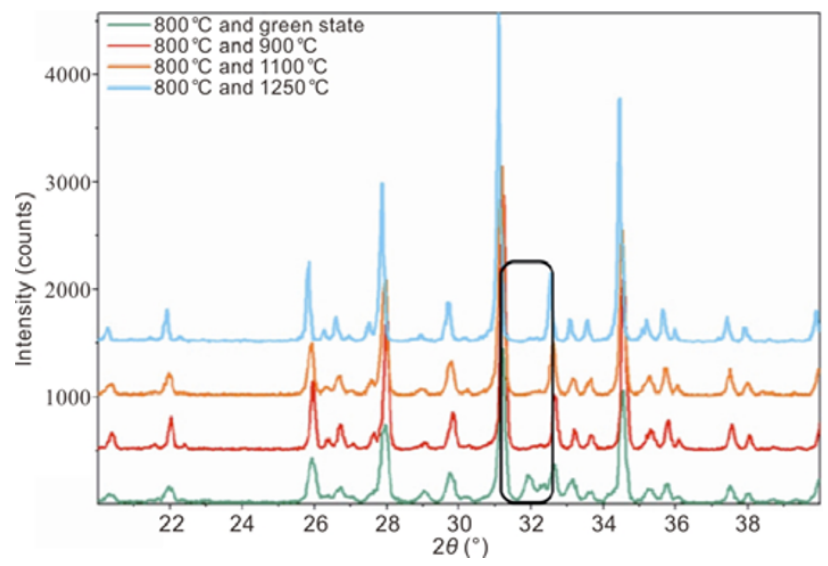

Fig. 2 XRD spectra for samples prepared with material calcined at $800{ }^{\circ} \mathrm{C}$ with respect to the different sintering stages. The green line is the green state, red line represents material sintered to $900{ }^{\circ} \mathrm{C}$, orange line represents sintered to $1100{ }^{\circ} \mathrm{C}$, and light blue represents sintered to $1250{ }^{\circ} \mathrm{C}$. The rectangle shape points out the lack of HA triplet peaks.
Rietveld analysis using MAUD program for crystalline phase quantification. The mean crystalline phase percentages and $95 \%$ confidence intervals for the $800{ }^{\circ} \mathrm{C}$ and $975{ }^{\circ} \mathrm{C}$ calcination temperature groups are presented in Table 1, respectively.

The XRD spectra for the green state, both calcination groups, showed both HA and $\beta$-TCP peaks, additionally the HA peaks were of higher intensity relative to $\beta$-TCP for the calcination group at $975{ }^{\circ} \mathrm{C}$ indicating the presence of higher amounts of HA compared to the calcination at $800{ }^{\circ} \mathrm{C}$. Such observation was validated through phase quantification by Rietveld refinement where a significantly higher amount of HA was present for the $975{ }^{\circ} \mathrm{C}, \sim 35 \%$, compared to $800{ }^{\circ} \mathrm{C}, \sim 11 \%$, calcination temperature. In

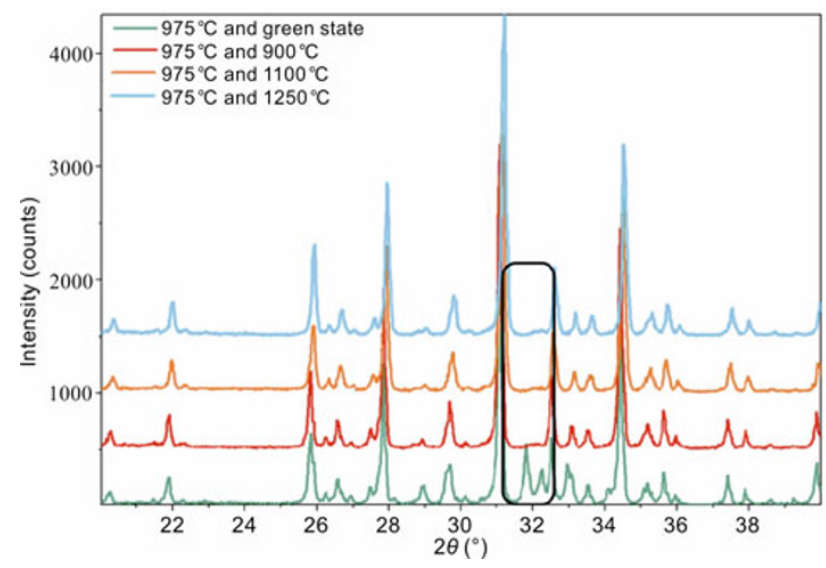

Fig. 3 XRD spectra for samples prepared with material calcined at $975{ }^{\circ} \mathrm{C}$ with respect to the different sintering stages. The green line is the green state, red line represents material sintered to $900{ }^{\circ} \mathrm{C}$, orange line represents sintered to $1100{ }^{\circ} \mathrm{C}$, and light blue represents sintered to $1250{ }^{\circ} \mathrm{C}$. The rectangle shape points out the lack of HA triplet peaks.

Table 1 Table indicating the percentage of each phase present in the calcination groups and subsequent sintering groups. The standard deviations are listed in parentheses. The letters depict statistically homogeneous groups within each phase between all groups evaluated

\begin{tabular}{|c|c|c|c|c|c|c|c|}
\hline \multicolumn{2}{|c|}{ Calcination temperature } & \multicolumn{3}{|c|}{$800{ }^{\circ} \mathrm{C}$} & \multicolumn{3}{|c|}{$975^{\circ} \mathrm{C}$} \\
\hline & & $\begin{array}{c}\% \mathrm{HA} \\
( \pm 95 \% \mathrm{CI})\end{array}$ & $\begin{array}{c}\% \% \beta-\mathrm{TCP} \\
( \pm 95 \% \mathrm{CI})\end{array}$ & $\begin{array}{l}\text { \%Ca Pyr. } \\
( \pm 95 \% \mathrm{CI})\end{array}$ & $\begin{array}{c}\% \mathrm{HA} \\
( \pm 95 \% \mathrm{CI})\end{array}$ & $\begin{array}{c}\% \beta-\mathrm{TCP} \\
( \pm 95 \% \mathrm{CI})\end{array}$ & $\begin{array}{l}\text { \%Ca Pyr. } \\
( \pm 95 \% \mathrm{CI})\end{array}$ \\
\hline \multirow{8}{*}{$\begin{array}{l}\text { Sintering } \\
\text { state }\end{array}$} & Green & $11.11^{\mathrm{b}}$ & $79.82^{\mathrm{c}}$ & $9.07^{\mathrm{c}}$ & $34.69^{\mathrm{a}}$ & $54.63^{\mathrm{e}}$ & $10.67^{\mathrm{c}}$ \\
\hline & state & $( \pm 0.34)$ & $( \pm 1.62)$ & $( \pm 1.28)$ & $( \pm 0.04)$ & $( \pm 0.38)$ & $( \pm 0.41)$ \\
\hline & $000{ }^{\circ} \mathrm{C}$ & $0.003^{\mathrm{e}}$ & $89.54^{\mathrm{a}}$ & $10.46^{\mathrm{b}, \mathrm{c}}$ & $1.71^{\mathrm{c}}$ & $85.07^{\mathrm{b}}$ & $13.22^{b}$ \\
\hline & 900 & $( \pm 0.01)$ & $( \pm 3.04)$ & $( \pm 3.05)$ & $( \pm 0.04)$ & $( \pm 0.10)$ & $( \pm 0.11)$ \\
\hline & & $0.104^{d}$ & $85.04^{b}$ & $14.85^{b}$ & $0.34^{\mathrm{d}}$ & $77.27^{\mathrm{c}, \mathrm{d}}$ & $22.39^{a}$ \\
\hline & $1100 \mathrm{C}$ & $( \pm 0.12)$ & $( \pm 1.17)$ & $( \pm 1.26)$ & $( \pm 0.65)$ & $( \pm 2.45)$ & $( \pm 2.74)$ \\
\hline & $1250^{\circ} \mathrm{C}$ & $0.03^{\mathrm{e}}$ & $87.27^{\mathrm{a}}$ & $12.70^{\mathrm{b}}$ & $0.00^{\mathrm{f}}$ & $75.73^{\mathrm{d}}$ & $24.26^{\mathrm{a}}$ \\
\hline & 1250 & $( \pm 0.06)$ & $( \pm 0.71)$ & $( \pm 0.67)$ & $( \pm 0.00)$ & $( \pm 0.21)$ & $( \pm 0.21)$ \\
\hline
\end{tabular}


addition, a substantial fraction, $\sim 10 \%$, of calcium pyrophosphate $\left(\mathrm{Ca}_{2} \mathrm{P}_{2} \mathrm{O}_{7}\right)$ was observed for both calcination temperatures. Thus, an order of magnitude increase in the presence of calcium pyrophosphate occurred following calcination of the materials, as well as an increase in the amount of the HA phase in the raw material calcined at $975{ }^{\circ} \mathrm{C}$.

The presence of calcium pyrophosphate prior to calcination has previously been demonstrated to be possible following different HA and $\beta$-TCP synthesis routes [17]:

$$
\begin{aligned}
& 2 \mathrm{CaHPO}_{4}+2 \mathrm{H}_{2} \mathrm{O}+\mathrm{Ca}_{10}\left(\mathrm{PO}_{4}\right) \cdot 6(\mathrm{OH})_{2} \\
\rightarrow & 2 \mathrm{Ca}_{3}\left(\mathrm{PO}_{4}\right)_{2}+2 \mathrm{Ca}_{2} \mathrm{P}_{2} \mathrm{O}_{7}+2 \mathrm{CaO}+6 \mathrm{H}_{2} \mathrm{O}
\end{aligned}
$$

or

$$
\begin{aligned}
& \mathrm{Ca}_{10-x}\left(\mathrm{HPO}_{4}\right)_{x}\left(\mathrm{PO}_{4}\right)_{6-x}(\mathrm{OH})_{2-x}(\mathrm{Ca}: \mathrm{P}=1.50) \\
\rightarrow & 2 \mathrm{Ca}_{3}\left(\mathrm{PO}_{4}\right)_{2}+\mathrm{Ca}_{2} \mathrm{P}_{2} \mathrm{O}_{7}+\mathrm{CaO}+\mathrm{H}_{2} \mathrm{O}
\end{aligned}
$$

In addition, the presence of calcium pyrophosphate at the levels observed following high temperature preparation at long dwell times have been previously identified and quantified through Rietveld refinement [17].

The phase transformation/evolution as a function of sintering temperature for materials calcined at $800{ }^{\circ} \mathrm{C}$ was evaluated, utilizing the green state phase fraction as baseline. A decrease in the amount of HA from $\sim 11 \%$ to less than $1 \%$ was along with a proportional increase in the amount of $\beta$-TCP, and minimal changes in the amount of calcium pyrophosphate were observed. For materials calcined at $975{ }^{\circ} \mathrm{C}$, a decrease in HA content from $\sim 35 \%$ to $\sim 2 \%, 0.3 \%$ and $0 \%$ at sintering temperatures of $900{ }^{\circ} \mathrm{C}, 1100{ }^{\circ} \mathrm{C}$ and $1250{ }^{\circ} \mathrm{C}$ was observed, respectively. After sintering to $900{ }^{\circ} \mathrm{C}$, increases of $\sim 30 \%$ and $\sim 3 \%$ were observed for $\beta$-TCP and calcium pyrophosphate, respectively. However, increasing sintering temperature to $1100{ }^{\circ} \mathrm{C}$ and $1250{ }^{\circ} \mathrm{C}$, proportional decrease and increase were observed for the $\beta$-TCP and calcium pyrophosphate phases respectively. These results differed from a previous study, which indicated a trend in which an increase in HA was observed. The difference between the previous study and this result can be possibly associated to the fact that calcium pyrophosphate was taken into account in this study [20].

The presence of the rapidly dissolving low stoichiometry phases such as calcium pyrophosphate is typically not detrimental to the initial host to grafting material response. Since the amount of secondary phase determined by Rietveld refinement was considerable $(\sim 10 \%)$, its initial rapid dissolution may enable further opening of the porous network, allowing the release of $\mathrm{Ca}$ and $\mathrm{P}$ to the wound-healing site along with larger diffusivity pathway for nutrients and oxygen, which are desirable features for osseoconduction. On the other hand, the release of large quantities of ions at short periods of time may be detrimental or toxic to the dynamically changing cell populating the wound-grafting material $[17,21]$. Although the chemical properties are important for grafting purposes, they are not the only important property to consider when tailoring grafting materials.

Following XRD and Rietveld analysis, material composition and chemical groups were further evaluated through Fourier transform-infrared (FT-IR) spectroscopy. Both calcination temperatures, $800{ }^{\circ} \mathrm{C}$ (Fig. 4) and $975{ }^{\circ} \mathrm{C}$ (Fig. 5) resulted in similar FT-IR spectra. In all of the sintering regimens of both calcination groups, sharp peaks were present in the $1100-1040 \mathrm{~cm}^{-1}$ range, as well as double peaks in $\sim 600 \mathrm{~cm}^{-1}$ range indicating the presence of phosphate groups $\left(\mathrm{PO}_{4}\right)$ [22]. These results are in agreement with the phase quantification results for both calcination temperatures at both green state and the three different sintering regimes, where either HA and $\beta$-TCP or a significant $\beta$-TCP percentage were present. Utilizing the green state spectra as baseline, a pronounced decrease in peak absorbance was observed for the $800{ }^{\circ} \mathrm{C}$ and $975{ }^{\circ} \mathrm{C}$ calcination temperatures as sintering temperature increased, which is explained by

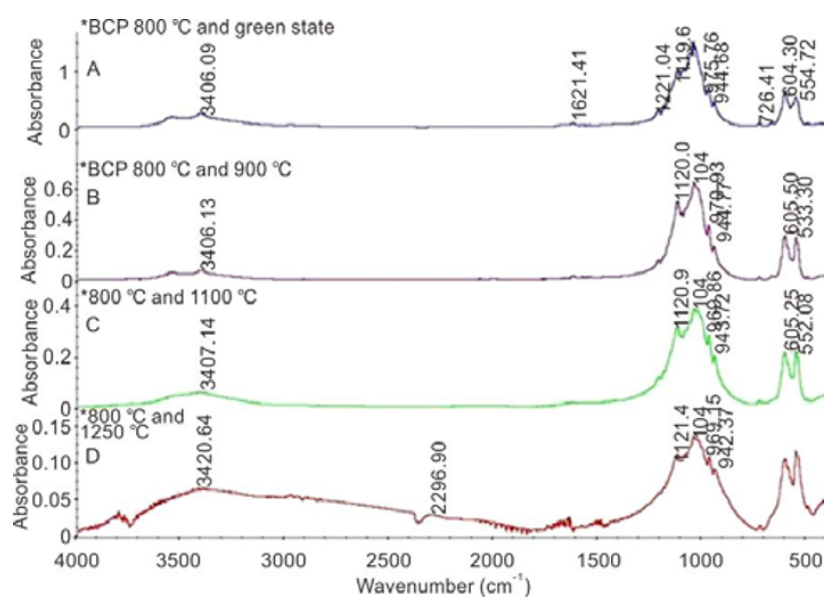

Fig. 4 FT-IR spectra for different sintering temperatures fabricated from materials calcined at $800{ }^{\circ} \mathrm{C}$ : (A) green state material, (B) sintered to $900{ }^{\circ} \mathrm{C}$, (C) sintered to $1100{ }^{\circ} \mathrm{C}$, and (D) sintered to $1250{ }^{\circ} \mathrm{C}$. 


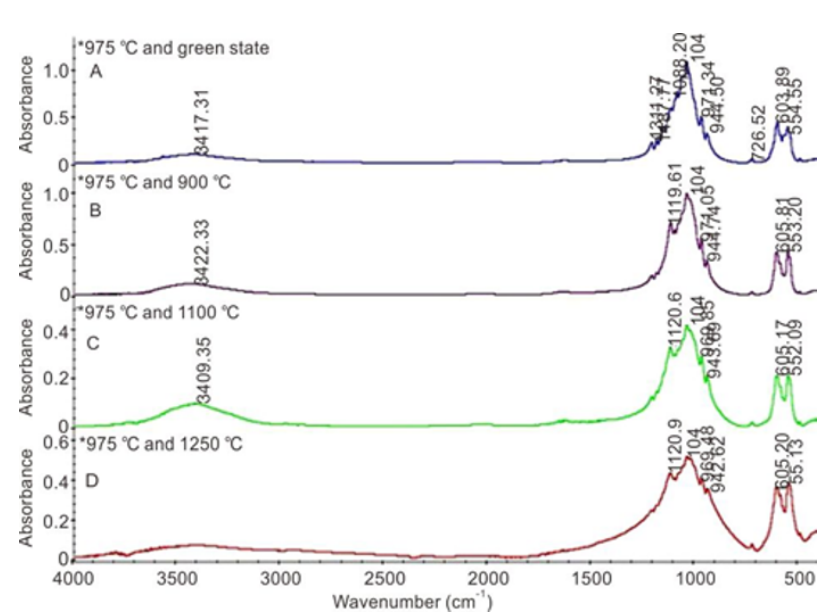

Fig. 5 FT-IR spectra for different sintering temperatures fabricated from materials calcined at $975{ }^{\circ} \mathrm{C}$ : (A) green state material, (B) sintered to $900{ }^{\circ} \mathrm{C}$, (C) sintered to $1100{ }^{\circ} \mathrm{C}$, and (D) sintered to $1250{ }^{\circ} \mathrm{C}$.

the substantial decrease in the HA phase content $[23,24]$.

The final step of the chemical assessment was performed using ICP to quantify the Ca:P molar ratio (Table 2). The theoretical $\mathrm{Ca}: \mathrm{P}$ ratio for pure HA, $\beta$-TCP and calcium pyrophosphate are 1.67, 1.5 and 1, respectively [25]. The samples with calcination temperature of $800{ }^{\circ} \mathrm{C}$ had a Ca:P ratio of $\sim 1.43$, while at $975{ }^{\circ} \mathrm{C}$ the ratio was lower at $\sim 1.37$. A significant effect in the Ca:P ratio was observed for the different calcination temperatures $\left(p<0.001^{\mathbb{1}}\right)$ whereas sintering temperature did not have a significant effect on the
Ca:P ratio $(p>0.70)$.

Porosity evaluation through helium pycnometry demonstrated that porosity slightly decreased for the $800{ }^{\circ} \mathrm{C}$ calcination temperature rods that were subjected to $900{ }^{\circ} \mathrm{C}$, whereas no variation in porosity was observed for the rods prepared with materials calcined at $975{ }^{\circ} \mathrm{C}$. These more pronounced microstructural changes were expected for the calcination at $800{ }^{\circ} \mathrm{C}$ as the temperature was lower than the sintering temperature, even though comparable post-sintering shrinkage was observed. Regardless of calcination temperature, scanning electron microscopy (SEM) depicted similar microstructural evolution, where a wider range of particle and pore sizes were observed at $900{ }^{\circ} \mathrm{C}$ and $1100{ }^{\circ} \mathrm{C}$. While a more uniform size distribution with larger particles and a more open structure was observed as the sintering temperature increased to $1250{ }^{\circ} \mathrm{C}$.

When increasing the sintering temperature to $1100{ }^{\circ} \mathrm{C}$, a decrease in porosity was observed for both calcination groups, followed by a significant increase in porosity when samples were sintered to $1250{ }^{\circ} \mathrm{C}$. Statistical evaluation indicated that both calcination and sintering temperatures presented a significant effect on percentage of porosity present $(p<0.001)$. Significantly higher percent porosity (mean $\pm 95 \%$ confidence interval) was observed for rods made of materials calcined at $975^{\circ} \mathrm{C}((48.16 \pm 0.78) \%)$ relative

Table 2 Mean $\pm 95 \%$ confidence interval for Ca:P values for calcination and subsequent sintering temperatures. The letters depict statistically homogeneous groups

\begin{tabular}{|c|c|c|c|c|c|c|c|}
\hline \multicolumn{2}{|c|}{ Calcination temperature } & \multicolumn{3}{|c|}{$800{ }^{\circ} \mathrm{C}$} & \multicolumn{3}{|c|}{$975^{\circ} \mathrm{C}$} \\
\hline & & Mean & Lower limit & Upper limit & Mean & Lower limit & Upper limit \\
\hline \multirow{4}{*}{$\begin{array}{c}\text { Sintering } \\
\text { state }\end{array}$} & Green state & $1.44^{\mathrm{a}}$ & 1.42 & 1.46 & $1.38^{\mathrm{b}}$ & 1.37 & 1.39 \\
\hline & $900{ }^{\circ} \mathrm{C}$ & $1.43^{\mathrm{a}}$ & 1.42 & 1.44 & $1.37^{\mathrm{b}}$ & 1.36 & 1.38 \\
\hline & $1100{ }^{\circ} \mathrm{C}$ & $1.43^{\mathrm{a}}$ & 1.41 & 1.45 & $1.38^{\mathrm{b}}$ & 1.37 & 1.39 \\
\hline & $1250{ }^{\circ} \mathrm{C}$ & $1.42^{\mathrm{a}}$ & 1.40 & 1.44 & $1.37^{\mathrm{b}}$ & 1.36 & 1.38 \\
\hline
\end{tabular}

Table 3 Percent porosity mean $\pm \mathbf{9 5 \%}$ confidence interval for the different groups. The letters represent statistically homogeneous groups

(Unit: \%)

\begin{tabular}{|c|c|c|c|c|c|c|c|}
\hline \multicolumn{2}{|c|}{ Calcination temperature } & \multicolumn{3}{|c|}{$800{ }^{\circ} \mathrm{C}$} & \multicolumn{3}{|c|}{$975^{\circ} \mathrm{C}$} \\
\hline & & Mean & Lower limit & Upper limit & Mean & Lower limit & Upper limit \\
\hline \multirow{4}{*}{$\begin{array}{c}\text { Sintering } \\
\text { state }\end{array}$} & Green state & $46.41^{b}$ & 45.55 & 47.27 & $52.15^{\mathrm{a}}$ & 47.76 & 56.54 \\
\hline & $900{ }^{\circ} \mathrm{C}$ & $44.21^{\mathrm{c}}$ & 43.22 & 45.20 & $51.99^{\mathrm{a}}$ & 49.03 & 54.95 \\
\hline & $1100{ }^{\circ} \mathrm{C}$ & $37.92^{\mathrm{d}}$ & 36.23 & 39.61 & $39.95^{\mathrm{d}}$ & 38.08 & 41.82 \\
\hline & $1250{ }^{\circ} \mathrm{C}$ & $50.61^{\mathrm{a}}$ & 48.02 & 53.20 & $48.52^{\mathrm{a}, \mathrm{b}}$ & 46.13 & 50.91 \\
\hline
\end{tabular}

(1) $p<0.05$ indicates a statistical significance. 
to $800{ }^{\circ} \mathrm{C} \quad((44.79 \pm 0.78) \%)$. Comparison between green state and the different sintering temperatures showed that both green state and rods sintered to $1250{ }^{\circ} \mathrm{C}$ presented significantly higher percent porosity relative to the ones sintered to $900{ }^{\circ} \mathrm{C}$ and $1100{ }^{\circ} \mathrm{C}$ (Table 3 ). The porosity results are in agreement with SEM, which showed more open structures for samples sintered to $1250{ }^{\circ} \mathrm{C}$ regardless of calcination temperature (Fig. 6).
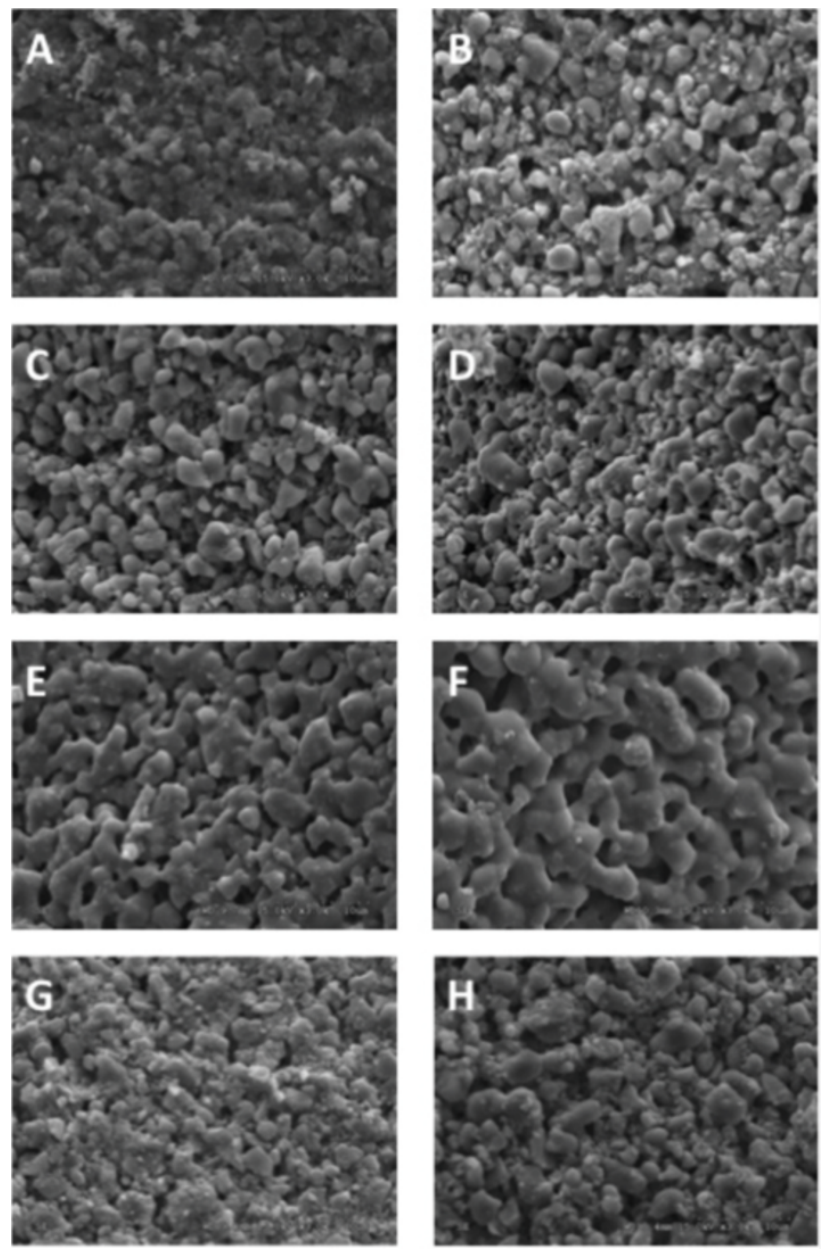

Fig. 6 This group of SEM images of $15 \% / 85 \%$ $\mathrm{HA} / \beta-\mathrm{TCP}$ was taken on Hitachi $\mathrm{S} 3500 \mathrm{~N}$ at $15.0 \mathrm{kV}$ and $3000 \mathrm{x}$. (A) Green state with materials calcined to $800{ }^{\circ} \mathrm{C}$; (B) green state with materials calcined to $975{ }^{\circ} \mathrm{C}$; (C, D) rods sintered to $900{ }^{\circ} \mathrm{C}$ with materials calcined at $800{ }^{\circ} \mathrm{C}$ and $975{ }^{\circ} \mathrm{C}$, respectively; (E, F) materials sintered to $1100{ }^{\circ} \mathrm{C}$ with initial materials prepared at $800{ }^{\circ} \mathrm{C}$ and $975{ }^{\circ} \mathrm{C}$, accordingly; $(\mathrm{G}, \mathrm{H}) 15 \% / 85 \%$ materials sintered to $1250{ }^{\circ} \mathrm{C}$ with calcination at $800{ }^{\circ} \mathrm{C}$ and $975{ }^{\circ} \mathrm{C}$, respectively.
Following chemical assessment, the mechanical properties, flexural strength and tensile strength were analyzed. Although statistical analysis showed comparable flexural strengths for both calcination temperatures, altogether, materials sintered to $1100{ }^{\circ} \mathrm{C}$ exhibited significantly higher flexural strength in comparison to $900{ }^{\circ} \mathrm{C}$ and $1250{ }^{\circ} \mathrm{C}$ sintering groups. The higher flexural strength may be explained by the lower degree of porosity observed for materials sintered to this specific temperature. The lower porosity created a more organized/compact material with fewer voids, which likely resulted in higher overall strength values.

When sintering temperature variation was considered, significantly higher flexural strength was observed for both $1100{ }^{\circ} \mathrm{C}$ and $1250{ }^{\circ} \mathrm{C}$ sintering groups relative to materials sintered to $900{ }^{\circ} \mathrm{C}$. Such difference in mechanical behavior may be accounted by the phase composition at $1100{ }^{\circ} \mathrm{C}$ and $1250{ }^{\circ} \mathrm{C}$, with minute fractions of the HA phase was observed even though porosity degree was similar for the $900{ }^{\circ} \mathrm{C}$ and $1250{ }^{\circ} \mathrm{C}$. Of all the experimental groups, the highest value observed was approximately $36.5 \%$ weaker than cancellous bone with an ultimate flexural strength of $\sim 40 \mathrm{MPa}[9,26]$. Statistical evaluation showed that calcination temperature did not have a significant effect on flexural strength $(p>0.8)$ while sintering temperatures did have an effect $(p<0.001)$. Comparable flexural strength (mean $\pm 95 \%$ confidence interval) was observed for rods calcined at $975{ }^{\circ} \mathrm{C}$ $((18.95 \pm 1.71) \mathrm{MPa})$ relative to $800{ }^{\circ} \mathrm{C} \quad((18.76 \pm$ 1.65) $\mathrm{MPa}$ ). Comparison between the different sintering temperatures showed that rods sintered to $1100{ }^{\circ} \mathrm{C}((24.91 \pm 2.51) \mathrm{MPa})$ presented significantly higher flexural strength relative to those sintered to $900{ }^{\circ} \mathrm{C}((9.73 \pm 1.98) \mathrm{MPa})$ and slightly higher for $1250{ }^{\circ} \mathrm{C}((22.34 \pm 2.09) \mathrm{MPa})$ (Fig. 7).

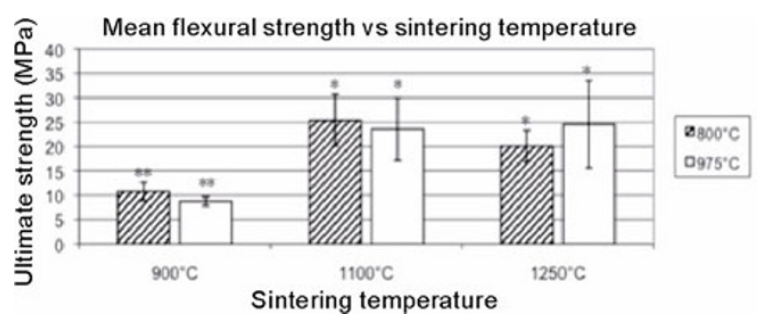

Fig. 7 Flexural strength mean $\pm 95 \%$ confidence interval for the different groups. The number of asterisks depicts statistically homogeneous groups. 
On the other hand, the $100 \%$ HA material sintered to $1250{ }^{\circ} \mathrm{C}$ and having a significantly lower porosity, exhibited the highest flexural stress, $\sim 80 \mathrm{MPa}$, roughly $50 \%$ higher than that of cancellous bone $[9,26]$. After sintering to $1250{ }^{\circ} \mathrm{C}$, rods fabricated from $100 \% \mathrm{HA}$ presented significantly higher $(p<0.001)$ flexural strength (mean $\pm 95 \%$ confidence interval) at $(79.07 \pm 7.42) \mathrm{MPa}$ relative to $15 \% / 85 \% \mathrm{HA} / \beta-\mathrm{TCP}$, which presented a value of $(20.11 \pm 0.92) \mathrm{MPa}$ (Fig. 8).

After analyzing ultimate flexural strength, tensile strength was explored utilizing diametral compression method. As in the flexural strength measurements, the results continued a similar trend as materials sintered to $1100{ }^{\circ} \mathrm{C}$ exhibited the highest tensile strength in comparison to $900{ }^{\circ} \mathrm{C}$ and $1250{ }^{\circ} \mathrm{C}$ sintering groups. Statistical analysis showed that both calcination and sintering temperatures presented a significant effect on tensile strength $(p<0.001)$. Significantly higher tensile strength values (mean $\pm 95 \%$ confidence interval) were observed for rods calcined at $800{ }^{\circ} \mathrm{C}((6.21 \pm 1.23)$ $\mathrm{MPa})$ relative to $975{ }^{\circ} \mathrm{C} \quad((3.08 \pm 1.23) \mathrm{MPa})$. Comparison between the different sintering temperatures showed that rods sintered to $1100{ }^{\circ} \mathrm{C}$ presented a significantly higher value tensile strength relative to those sintered to $900{ }^{\circ} \mathrm{C}$ and $1250{ }^{\circ} \mathrm{C}$ at values of $(6.57 \pm 1.23) \mathrm{MPa},(1.99 \pm 1.01) \mathrm{MPa}$, and $(5.38 \pm 1.23) \mathrm{MPa}$, respectively (Fig. 9).

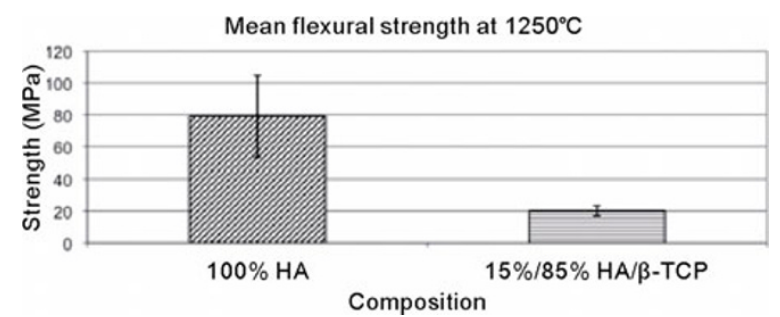

Fig. 8 Flexural strength mean $\pm 95 \%$ confidence interval showing a significantly higher value for the $100 \%$ HA group $(p<0.001)$.

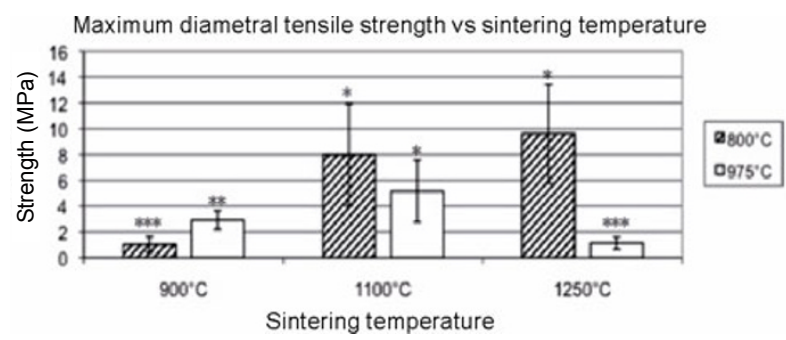

Fig. 9 Tensile strength mean $\pm 95 \%$ confidence interval for the different groups. The number of asterisks depicts statistically homogeneous groups.
Sintering rods fabricated from $100 \% \mathrm{HA}$ to $1250{ }^{\circ} \mathrm{C}$ presented significantly higher $(p<0.001)$ tensile strength (mean $\pm 95 \%$ confidence interval) at $(19.49 \pm 6.21) \mathrm{MPa}$ relative to $15 \% / 85 \% \mathrm{HA} / \beta-\mathrm{TCP}$, which presented a value of $(9.61 \pm 3.81) \mathrm{MPa}$ (Fig. 10). Even when comparing the $100 \%$ HA material, the highest value observed for experimental groups were still about $50 \%$ short, which is in agreement with a previous study by Martin and Brown [27].

However, in contrast to the results observed for flexural strength, the materials calcined at $800{ }^{\circ} \mathrm{C}$ exhibited a higher strength relative to those calcined at $975{ }^{\circ} \mathrm{C}$. While the diametral tensile strength monotonically increased for the material calcined at $800{ }^{\circ} \mathrm{C}$ as a function of sintering temperature, a slight increase was observed from $900{ }^{\circ} \mathrm{C}$ to $1100{ }^{\circ} \mathrm{C}$ groups, followed by a sharp decrease in strength when the sintering temperature was $1250{ }^{\circ} \mathrm{C}$ for the materials calcined to $975{ }^{\circ} \mathrm{C}$.

Even though similarities were observed between flexural strength and diametral tensile strength testings, the contrasting trends observed between methods are indicative that due to extrusion, the flaw population likely varied throughout the rod volume as a function of calcination temperatures as well as sintering temperature. Specific to the mechanical testing methods utilized in the present study, 3-point bending provides information concerning the effects of flaw populations at or in proximity with the specimen surface, whereas the diametral tensile test provides information on the flaw population present in the material bulk. Nonetheless, the bulk and surface properties are key design parameters, especially since site-specific defects will require different geometric configurations.

Altogether, since various chemical formulations and mechanical properties were obtained by extruding materials processed at different calcination

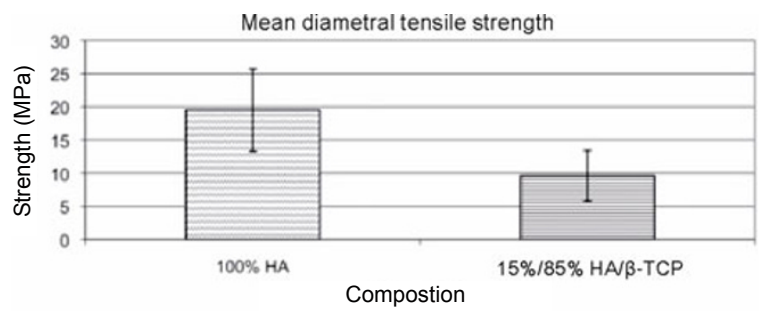

Fig. 10 Tensile strength mean $\pm 95 \%$ confidence interval showing a significantly higher value for the $100 \%$ HA group $(p<0.001)$. 
temperatures subsequently subjected to various sintering regimens, a factorial study design including microstructural evolution and their effects on temporal in vitro and in vivo behaviors are desirable for better tailoring scaffolds for bone regeneration.

\section{Acknowledgements}

Professor Van Thompson from King's College London Dental Institute (https://kclpure.kcl.ac.uk/portal/van. thompson.html) is gratefully acknowledged for his guidance as well as for putting this group of authors together to complete this work and manuscript.

Open Access: This article is distributed under the terms of the Creative Commons Attribution Noncommercial License which permits any noncommercial use, distribution, and reproduction in any medium, provided the original author(s) and source are credited.

\section{References}

[1] Stoll C, Mengsteab S, Stoll D, et al. Analysis of polymorphic $T G F B 1$ codons 10,25 , and 263 in a German patient group with non-syndromic cleft lip, alveolus, and palate compared with healthy adults. BMC Med Genet 2004, 5: 15.

[2] Seitz H, Rieder W, Irsen S, et al. Three-dimensional printing of porous ceramic scaffolds for bone tissue engineering. J Biomed Mater Res B: Appl Biomater 2005, 74B: 782-788.

[3] Moore WR, Graves SE, Bain GI. Synthetic bone graft substitutes. ANZ J Surg 2001, 71: 354-361.

[4] Kivrak N, Taş AC. Synthesis of calcium hydroxyapatite-tricalcium phosphate (HA-TCP) composite bioceramic powders and their sintering behavior. J Am Ceram Soc 1998, 81: 2245-2252.

[5] Daculsi G, LeGeros RZ. Tricalcium phosphate/hydroxyapatite biphasic ceramics. In Bioceramics and Their Clinical Applications. Kokubo T, Ed. Cambridge, UK: Woodhead Publishing, 2008: 395-423.

[6] LeGeros RZ, LeGeros JP. Hydroxyapatite. In Bioceramics and Their Clinical Applications. Kokubo T, Ed. Cambridge, UK: Woodhead Publishing, 2008: 367-394.

[7] Smay J. Dissolution of CaS filled, HA:beta-TCP scaffolds with hierarchical pore network. IADR, Miami, FL, USA, 2009: 1-16.

[8] Rey C, Combes C, Drouet C. Tricalcium phosphate-based ceramics. In Bioceramics and Their Clinical Applications. Kokubo T, Ed. Cambridge, UK: Woodhead Publishing, 2008: 326-366.

[9] Pines M, Witek L, Clark E, et al. Flexural strength of degradable 3-D scaffolds for critical bone repair. IADR, Barcelona, Spain, 2010. Available at https://iadr.confex.com/iadr/2010barce/preliminarypr ogram/abstract_133134.htm.

[10] Moore JR, Phillips TW, Weiland AJ, et al. Allogenic transplants of bone revascularized by microvascular anastomoses: A preliminary study. $J$ Orthop Res 1983, 1: 352-360.

[11] Cretiu-Vasiliu CE. Assembly of hydroxyl apatite: $\beta$-tricalcium phosphate: Calcium sulfate bone eingineering scaffolds. Master Thesis. Stillwater, OK, USA: Oklahoma State University, 2008.

[12] Smay JE, Cesarano III J, Lewis JA. Colloidal inks for directed assembly of 3-D periodic structures. Langmuir 2002, 18: 5429-5437.

[13] Guda T, Walker JA, Singleton BM, et al. Guided bone regeneration in long-bone defects with a structural hydroxyapatite graft and collagen membrane. Tissue Eng Part A 2012, DOI: 10.1089/ten.tea.2012.0057.

[14] Mijares DQ. Synthetic bone mineral (SBM): Prevention of bone loss induced by estrogen deficiency in a rat model. Master Thesis. New York, NY, USA: New York University, 2009.

[15] Young RA. The Rietveld Method. Oxford, UK: Oxford University Press, 1995.

[16] Taylor JC. Rietveld Made Easy: A Practical Guide to the Understanding of the Method and Successful Phase Quantifications. Sietronics Pty Limited, 2003.

[17] Coelho PG, Coimbra ME, Ribeiro C, et al. Physico/chemical characterization and preliminary human histology assessment of a $\beta$-TCP particulate material for bone augmentation. Mat Sci Eng C 2009, 29: 2085-2091.

[18] Fell JT, Newton JM. Determination of tablet strength by the diametral-compression test. J Pharm Sci 1970, 59: 688-691.

[19] Miranda P, Saiz E, Gryn K, et al. Sintering and robocasting of $\beta$-tricalcium phosphate scaffolds for orthopaedic applications. Acta Biomater 2006, 2: 457-466.

[20] Kong Y-M, Kim H-E, Kim H-W. Phase conversion of tricalcium phosphate into Ca-deficient apatite during sintering of hydroxyapatite-tricalcium phosphate biphasic ceramics. J Biomed Mater Res B: Appl Biomater 2008, 84B: 334-339.

[21] Hench LL, Wilson J. An Introduction to Bioceramics. Singapore: World Scientific, 1993. 
[22] Greiner-Wronowa E, Paluszkiewicz C, Stoch L. Applying FTIR spectroscopy in the study of archeometric sensor glasses. J Mol Struct 1999, 511-512: 199-204.

[23] LeGeros RZ. Properties of osteoconductive biomaterials: Calcium phosphates. Clin Orthop Relat Res 2002, 395: 81-98.

[24] LeGeros RZ, Lin S, Rohanizadeh R, et al. Biphasic calcium phosphate bioceramics: Preparation, properties and applications. J Mater Sci: Mater $M$ 2003, 14: 201-209.

[25] Raynaud S, Champion E, Bernache-Assollant D, et al. Calcium phosphate apatites with variable $\mathrm{Ca} / \mathrm{P}$ atomic ratio I. Synthesis, characterisation and thermal stability of powders. Biomaterials 2002, 23: 1065-1072.

[26] Lewis KN, Thomas MV, Puleo DA. Mechanical and degradation behavior of polymer-calcium sulfate composites. J Mater Sci: Mater M 2006, 17: 531-537.

[27] Martin RI, Brown PW. Mechanical properties of hydroxyapatite formed at physiological temperature. J Mater Sci: Mater M 1995, 6: 138-143. 